of the International Council of Scientific Unions, with its secretariat in Brussels ; and it is concerned with the various scientific aspects of radio communication and radio physics, in many branches of which international discussion and co-operation is beneficial in stimulating both theoretical and experimental research. At the previous general assembly of the U.R.S.I. held in London in 1934, Prof. E. V. Appleton was elected president, and he is also chairman of the British National Committee, of which Dr. E. H. Rayner is secretary. Other members of this committee who will be attending the forthcoming meeting in Italy include Prof. S. Chapman, Mr. T. E. Eckersley, Mr. E. B. Moullin, Mr. J. A. Ratcliffe, Dr. R. L. Smith-Rose and Mr. R. A. Watson Watt. It is anticipated that representatives of some twelve or more other nations will also be in attendance. The work of the General Assembly is divided among five commissions dealing respectively with radio measurements and standards, the propagation of waves, atmospherics, liaison and radio physics. The opening meeting will take place on September 4 at Venice, where most of the business of the Assembly will be carried out during the ensuing week. The formal closing meeting takes place in Rome, and various technical visits and other appropriate engagements of interest are included in the programme.

\section{Imperial Veterinary Conference}

AN Imperial Veterinary Conference will be held at the Royal Veterinary College, Camden Town, London, N.W.1, on August 15-19. The subjects to be discussed will include the work of the Imperial Bureau of Animal Health, foot-and-mouth disease and certain other virus diseases, Johne's disease, bovine mastitis, caseous lymphadenitis of sheep, sheep blowflies, fowl paralysis and chronic bovine hæmaturia.

\section{Announcements}

The Jenner Medal of the Royal Society of Medicine, which is awarded for distinguished work in epidemiological research or for pre-eminence in the prevention and control of epidemic disease, was presented to Sir Arthur Newsholme on July 19.

THळ Queen Mary has established a new record for the east to west crossing of the Atlantic. She berthed at New York on August 8, after having covered the distance from the Bishop Rock to the Ambrose Channel lightship in 3 days 21 hours 48 minutes, at an average speed of 30.99 knots.

IT is announced by the Berlin correspondent of The Times that a new height record for a glider was set up at Wasserkuppe by Capt. Walther Drechsel on August 5, when he ascended to $23,190 \mathrm{ft}$. The machine, a Minimoa glider, was towed to a height of about $3000 \mathrm{ft}$. and then released.

THRough the generosity of the late Mr. Herbert Harlow of Bradford, the Bradford Technical College has been able to establish a Harlow fellowship of the value of $£ 250$ a year for research to be carried out at the Technical College, Bradford, in one of the branches of science relating to the textile industry or the dyeing industry. Mr. R. Williamson has been appointed to the first fellowship.

AN Advisory Committee on Blindness, including its prevention and treatment, has recently been formed by the Minister of Health. The following have been appointed members of the Committee : Dr. P. M. Evans (chairman), H. R. Bickerton, J. D. Magor Cardell, Miss Grace Cracknall, James Ferguson, Percy Fleming, N. Bishop Harman, Dr. E. K. Macdonald, Miss Ida Mann, R. Foster Moore, G. F. Mowatt, Sir John Parsons and A. H. H. Sinclair. The Committee has been appointed for a period of three years. Mr. H. G. Benjamin, of the Ministry of Health, will be secretary, and Dr. A. E. Hallinan, of the Ministry of Health, will be medical secretary of the Committee.

THE following awards for 1938-39 have been made by the Salters' Institute of Industrial Chemistry and approved by the Court of the Salters' Company. Fellowships have been renewed in the case of Messrs. A. J. Shorter (to the University of Illinois), J. L. Tuck (at the University of Oxford) and to S. H. Wade (at Imperial College, London). Fellowships have been awarded to H. D. Anderson (University of Oxford), A. Cameron (Imperial College, London), H. S. Corran (University of Cambridge) and R. N. Haward (University of Cambridge). The Salters' Institute has also awarded fifty grants-in-aid to young men employed in chemical works in or near London to assist them in their studies.

THE following appointments and promotion have been made in the Colonial Service: H. C. Thorpe to be plant breeder, Kenya; M. H. C. Glyn, to be veterinary officer, Northern Rhodesia; W. G. G. Pevie, to be veterinary officer, Tanganyika Territory; D. A. Frye, to be assistant analyst, Analyst's Department, Straits Settlements; J. R. E. Hindson (agricultural superintendent, Gold Coast), to be agricultural officer, Northern Rhodesia; R. M. Nattrass (plant pathologist, Cyprus), to be senior plant pathologist, Kenya ; Gunn Lay Teik (assistant analyst), to be chemist, Department of Agriculture, Federated Malay States ; W. Molegode (officer of Class I, Grade I, Agricultural Department), to be agricultural officer (Propaganda), Ceylon.

Dr. Wendell Meredith Stanley, of the Rockefeller Institute, Princeton, has been awarded the Rosenberger Medal of the University of Chicago in recognition of his isolation of erystalline forms of the filtrable viruses. The Rosenberger Medal for distinguished achievement in the advancement of learning or for notably great service in the promotion of human welfare has been awarded five times previously.

THE first International Congress for Forensic and Social Medicine will be held at Bonn on September 22-24 under the presidency of Prof. Pietrusky, director of the Bonn Institute of Forensic Medicine. Further information can be obtained from Prof. Schrader, Franzosenweg 1, Halle a.d.S. 